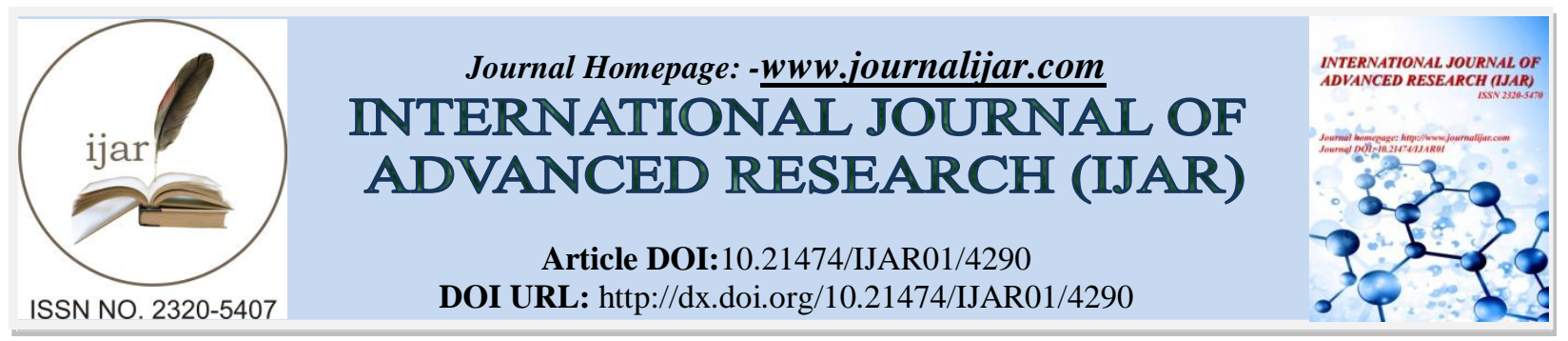

RESEARCH ARTICLE

\title{
CASE STUDY: EFFECT OF UNANI MEDICINE ON FROSTBITE (KHASAR-E-TASQEEU).
}

\section{Shahnaz H. Kawoosa ${ }^{1}$, Shafia M. Allaqaband ${ }^{2}$ and Shagufta Nisa ${ }^{3}$}

1. Assistant Professor, Illaj bit Tadbeer, Kashmir Tibbia College, Shilvath Sumbal, Jammu and Kashmir.

2. Assistant Professor, Department of Medicine, Kashmir Tibbia College, Shilvath Sumbal, Jammu and Kashmir.

3. Associate Professor, Department of Physiology, Kashmir Tibbia College, Shilvath Sumbal, Jammu and Kashmir.

\section{Manuscript Info}

(n.........................

Manuscript History

Received: 28 March 2017

Final Accepted: 30 April 2017

Published: May 2017

Key words:-

frostbite, dorsum, high altitude areas

\section{Abstract}

Background: we report a case 16 years old young female who suffered from frostbite on dorsum of both feet.

Case presentation: socio-demographic background, cause, resulting lesion and subsequent management by Unani system of medicine are discussed.

Conclusion: such cases are frequently found in high altitude areas and can be managed well by Unani system of medicine.

Copy Right, IJAR, 2017,. All rights reserved.

\section{Introduction:-}

Frostbite is a peripheral cold injuries which include both freezing and non freezing to tissue. Frostbite occurs when tissue temperature drops below $0^{0} \mathrm{C}$. (1)

Khasar-e-tasqeeu is a term described by unani physician thousands of years ago for frost bite. Khasar-e-tasqeeu is result of exposure to severe cold climate as a result of which skin becomes pale in colour.(2) It can involve hands, feet, nose, ear, etc. (3)(4) It initially appears as wrinkles, gradually it becomes dry, black in colour, numbness and results in gangrene formation (3)

Khasar is an acute inflammation as a result of cold exposure. Acute inflammation is because of decreased peripheral circulation which leads to injury in microvasculature, as a result increased oozing and oedema formation takes place. Oedema formation leads to localized pressure on surrounding tissue, which results in gangrene formation.(3)

Clinically frostbite has been classified into three grades : Grade -I:Anaesthesia, erythema. Grade -II: appearance of superficial vasculation surrounded by oedema and erythema. Grade -III: Haemorrhagic vesicles reflect a serious injury to microvasculature. Grade fourth: Damage subcuticular muscular and osseous tissue.(1)

Prevalence: frost bite is one of the most common cold injuries (5), in common population, it is uncommon despite 100 million population is at risk in areas where sub zero temperature occur at some period of the year. (6) in mountaineers at high altitude cases occur frequently. (5)

The proposition of mild frostbite occurring annually is $12.9 \%$ (14.2\% and $11.9 \%$ for men and women respectively). (7)

Corresponding Author:-Shafia Mushtaq Allaqaband.

Address:-Assistant Professor, Department of Medicine, Kashmir Tibbia College, Shilvath Sumbal, 
Case report: a patient with age 16years student female came to O.P.D. with symptoms itching, swelling, redness and white scaly skin of bilateral dorsal surface of feet for 20 days. Symptoms were gradual in onset and had occurred every now and then since three months. Its onset was aggravated with winter season patient has history of mild frost bite (grade 1) since many years but this winter was severe (grade 3). No H/O hypertension, D.M, T.B, rheumatoid arthritis or any other chronic and allergic disease was present. Patient was not taking any medicine for any previous ailments. No family history of H/O hypertension, D.M, Raynaud's phenomenon was present. Symptoms, aggravated with frequent exposure to warm or cold temperature. Frostbite lesion was many in number on both feet. Two lesions were big in size and were ulcerative with indurated margins surrounded by white or grey tissue (Figure 1).

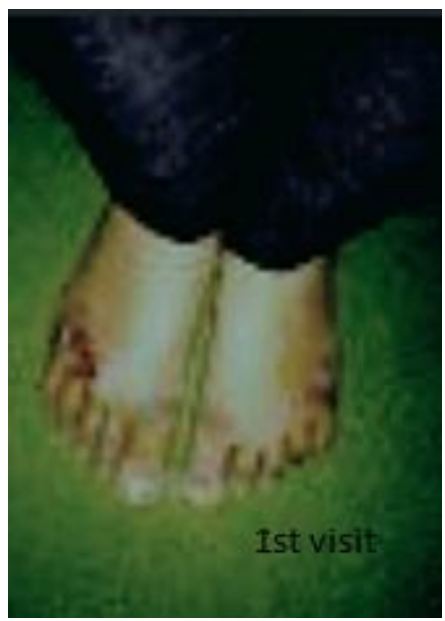

Figure 1

Surrounding areas were edematous and tender. Photographs were taken before treatment ( 0 day), third week $\left(21^{\text {st }}\right.$ day) and fifth week ( $35^{\text {th }}$ day) to compare the effect of treatment.

Treatment included both local and systemic. Locally, Pashoya (foot bath) was given to patient. Pashoya is a regimenal therapy in which foot are dipped in medicated lukewarm water for 15 minutes. Here Pashoya consisted of Barg-e-Heena (leaves of Lawsonia inermis), Barg-e-Neem (leaves of Melia azadirachta) and Parsiyaonsaan (Adiantum capillus) in equal quantities twice a day for one month.

Systemically, blood purifier, Arq murakab musafikhoon, 3 tsf, thrice daily with water for three weeks. Follow up was done weekly.

After one month patient was given mild moisturizer for local application.

\section{Results:-}

Symptoms such as itching and redness decreased moderately after one week. No significant change was seen in lesions.

After three weeks, symptomatically patient had no itching, oedema, redness and tenderness. Ulcers were healed with significant improvement in lesions on both feet. The affected areas were left with depigmentation and dry scaly skin. (figure 2)

After five weeks, lesions were completely healed with less dry scaly skin. 


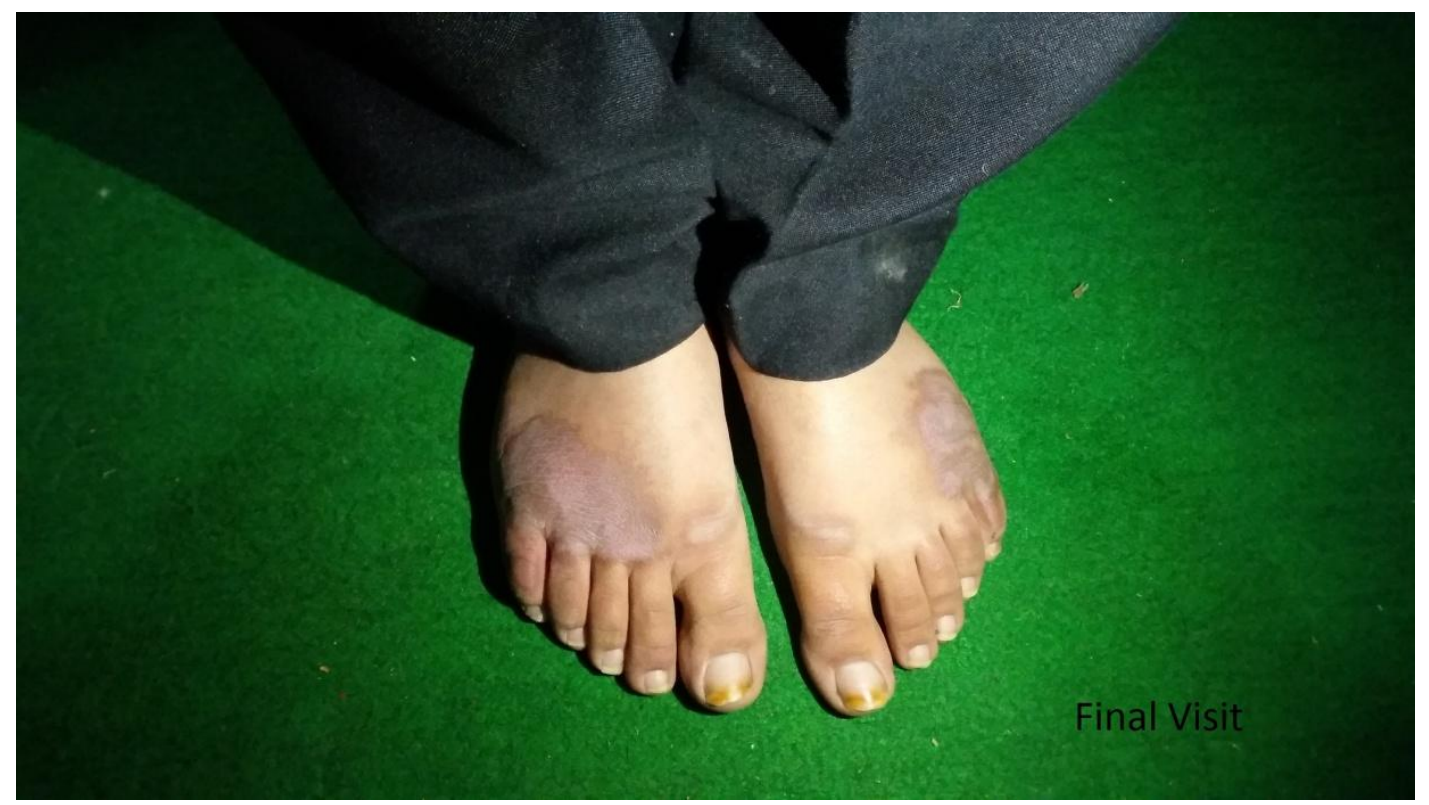

Figure 2

\section{Discussion:-}

From the above results it is evident that Unani treatment for frost bite is very effect. Barg-e-Heena has known action such as Musakin (analgesic), Mujafif (desiccative), Muhalil (anti-inflammatory); Barg-e-Neem has known action such as Musakin (analgesic), Muhalil (anti-inflammatory), DafahTafun (antiseptic)and Parsiyaonsaan is Muhalil (anti inflammatory), jali (detergent) and mulatif (demulcent).8,9 This could be attributed to the fact that herbs used in pashoya are bestowed with anti-inflammatory, detergent, demulcent, analgesic, antiseptic, antibacterial, desiccative and anti-ulcerative properties.

Arq murakab musafikhoon is used orally and it is compound unani formulation. Its composition has principle component as neem which is Musakin (analgesic), Muhalil (anti-inflammatory) and DafahTafun (antiseptic) in nature. 8,9

\section{Conclusion:-}

Above case study has promising results and further planned study can be done on large number of subjects.

\section{References:-}

1. Kasper, braunwald, fauci, hausei, longi. Harrisons principles of internal medicine. U.S.A: Mcgraw Hill medical publishing division. Vol. I. $16^{\mathrm{TH}}$ Edition. Page no.124.

2. Waseem ahmad azmi. Moalijat.New delhi: quami council . Vol. IV 2012. Page 181

3. Alama Najeebudin Samarkhandi. Trans.(hakim kabirudin). Sharah asbaab.New delhi:Aijaz publication Vol. 4. Page 489

4. P.N Behl. Practice of dermatology. New delhi: CBS publishers and distributors. 2000. Page 108.

5. Harirchi I, Arvin A, Vash JH, Zafarmand V: Frostbite: incidence and predisposing factors in mountaineers. British Journal of Sports Medicine 2005, 39:898-901.

6. Ward M: Frostbite. Br Med J 1974, 1(5897):67-70.

7. Mäkinen $\mathrm{TM}^{1}$, Jokelainen $J$, Näyhä $S$, Laatikainen $T$, Jousilahti $P$, Hassi J. Occurrence of frostbite in the general population--work-related and individual factors. Scand J Work Environ Health. 2009 Oct;35(5):384-93

8. Kabiruddin H,Mazaanul Mufradat. Kohinoor book depot motiya mahal jamiamasjid delhi. 2000. P 161, 581,552

9. Kabiruddin H, Ilmul advia nafeesi. Ajaz publishing house, darya gunj new delhi 2007 p.255, 348, 117 